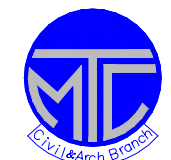

ICCAE

Military Technical College

Kobry Elkobbah,

Cairo, Egypt 6hㅡ International Conference On Civil \& Architecture Engineering

\title{
Study of Isolation Methods of Underground Structures By using Admixtures of Concrete
}

\author{
Sami M. khaddour ${ }^{1}$, Adham A. Elsayed ${ }^{2}$, Mohamed A. Fergala ${ }^{3}$
}

\begin{abstract}
Waterproofing of underground structures is frequently a problem and a range of solutions have been tried in the last two decades. Dominating the market are PVC and HDPE (high density poly ethylene) sheet membranes, but recently the alternative, is concrete admixtures for water permeability reducing and so that use in concrete isolation (waterproofing), the longevity of a concrete structure is influenced by the permeability of the concrete, In this research, it has been addition ADDICRETE DM2 and PLASTOCRETE $\mathrm{N}$ to the mixture by difference ratio. $1 \%, 0.5 \%, 0.45 \%, 0.35 \%$ of cement weight, constant ratio from , sand, gravel, cement and water $\mathrm{W} / \mathrm{C}=0.45$ in all tests that used in the research . The study of these tests by measuring the permeability of concrete specimens prepared in the laboratory. Many tests were carried out and the results were presented.
\end{abstract}

Keywords: waterproofing; ADDICRETE DM2, PLASTOCRETE-N, permeability, concrete.

1-M.S , Candidate, Syria.

2-Egyptian Armed Forces.

3-Prof. Ain Shams University, Cairo, Egypt. 


\section{Introduction}

Since the underground structures have existed, there has always been the problem of water infiltrations. Historically, we all know that water and moisture are the most important elements that cause damage to concrete structures. The reason is that the groundwater contains chemical substances that damage the structure and may lead to reinforcement corrosion and losing the structural ability of the structure. Some concrete crakes that would allow larger amounts of water and humidity to leak into concrete. As a result, the structure would collapse if it is not maintained properly. Such a problem would not enable us to use and infest this structure in an optimum right way, and would damage the materials stored inside and affected by humidity. Therefore, it was must to protect these structures against humidity by many ways. One of these ways by adding water isolating substances to the concrete mix to greatly reduce water permeability through concrete ${ }^{(1)}$

This substance must be designed and conducted according to the standards of the material used for isolation. It should be used according to the right rates, type of the structure, and the surrounding circumstances, as well.

The main objectives of the research are to study the mechanical properties of concrete and the improvement these properties by adding waterproofing using various mount percentages and two types of waterproofing (ADDICRETE DM2-PLASTOCRET-N) series of experimental studies were carried out on plain concrete with added, ADDICRETE DM2 and PLASTOCRETE-N in order to investigate their properties and influence on the water permeability of concrete. The following tests were carried out and the results of such are displayed and discussed in this research.

\section{Scope of admixtures:}

To create waterproofing concrete without the need for addition membranes or perhaps supplemented with additional protection is certain instances.

- Result in a concrete that is durable to environmental degradation, primarily through reduction in permeability, and perhaps also providing supplemental chemical protection.

- Result in no major side effects to the concrete i.e. will not seriously affect concrete properties in negative manner.

- And that it is not overly expensive.

\section{The experimental description:}

The water impermeability test results on plates were presented in tables and figures. Each water impermeability test ${ }^{(2)}$ result was the average for 3 test specimens, as a rule testing of specimens begins at an age of 28 days. Any device can serve as a test apparatus into which the test specimen of the given dimensions can be installed, so that the water pressure acts on the required face and the remaining faces can be observed see Figure (1) and which allows the following test procedure to carry out. Hence the water pressure may act downwards on the 
test specimens. At first a pressure of 1 bar is applied for 48 hours, then pressures of 3 bar and 7 bar, each for 24 hours, one after the other. The test can be stopped if water comes through. Next, one must determine whether and under what pressure and, as far as possible, also after what time the test specimen becomes damp, apart from the surface exposed to the water. Immediately after the test, the test specimen - plate lying flat- is to be plate in the middle (photo.1), e.g. by compression applied on two round steel bars lying on opposite sides, above and below. As soon as the split surface has dried somewhat, the greatest penetration depth in $\mathrm{mm}$ and the distribution of the water penetration are to be established. When splitting and making this examination, the side of the test specimen exposed to the water pressure should face downwards. The greatest water penetration depth $^{3}$, measured on the tested concrete, is taken as the average value of the greatest penetration depth on three test specimens

\section{Water pressure}

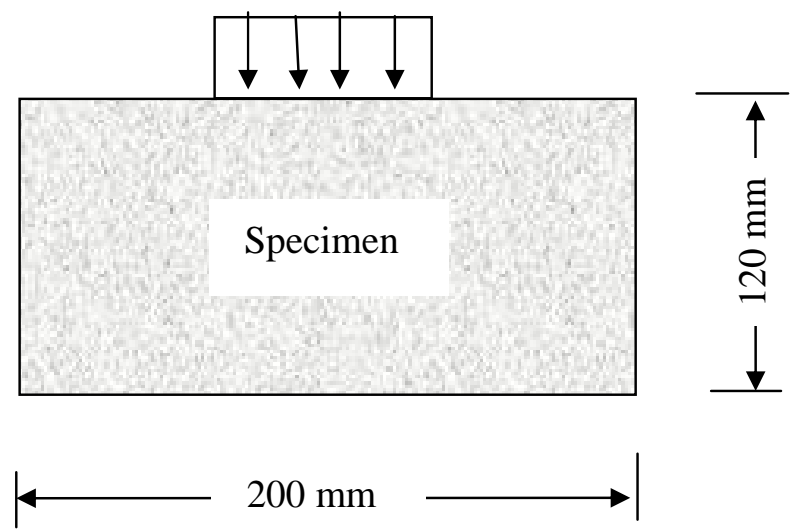

Figure (1) Testing water impermeability on sample, $120 \mathrm{mmx} 200 \mathrm{mmx} 200 \mathrm{~mm}$
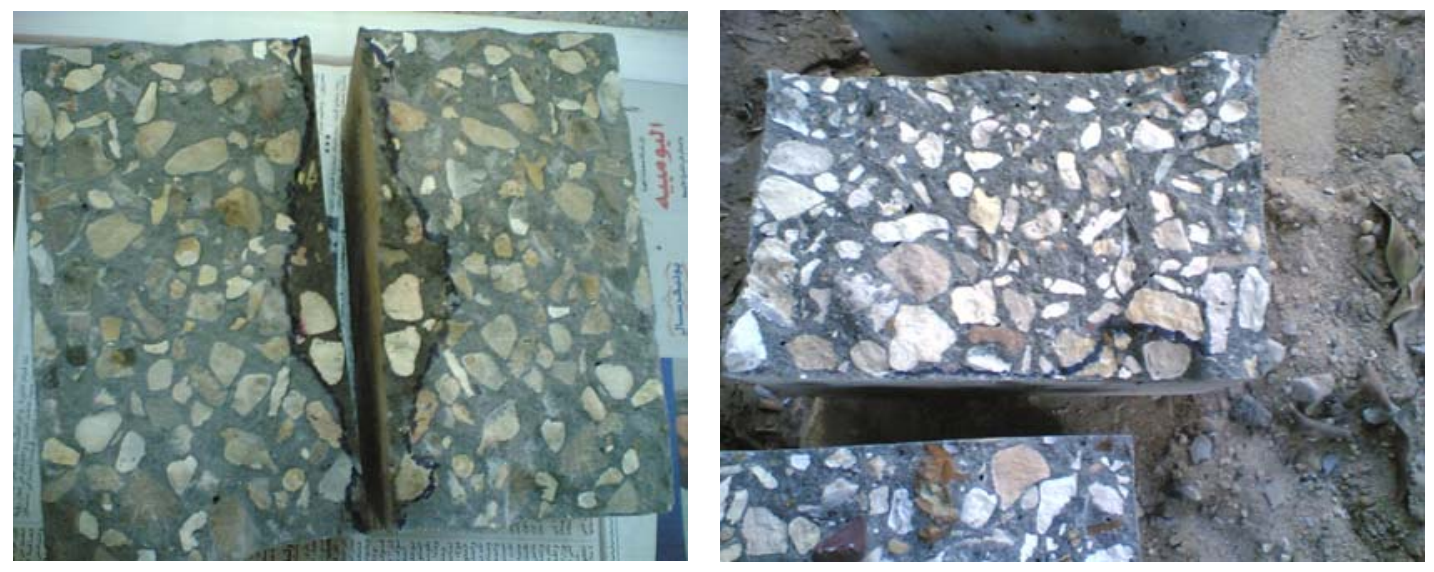

Photo (1) Depth of water penetration into sample after test. 


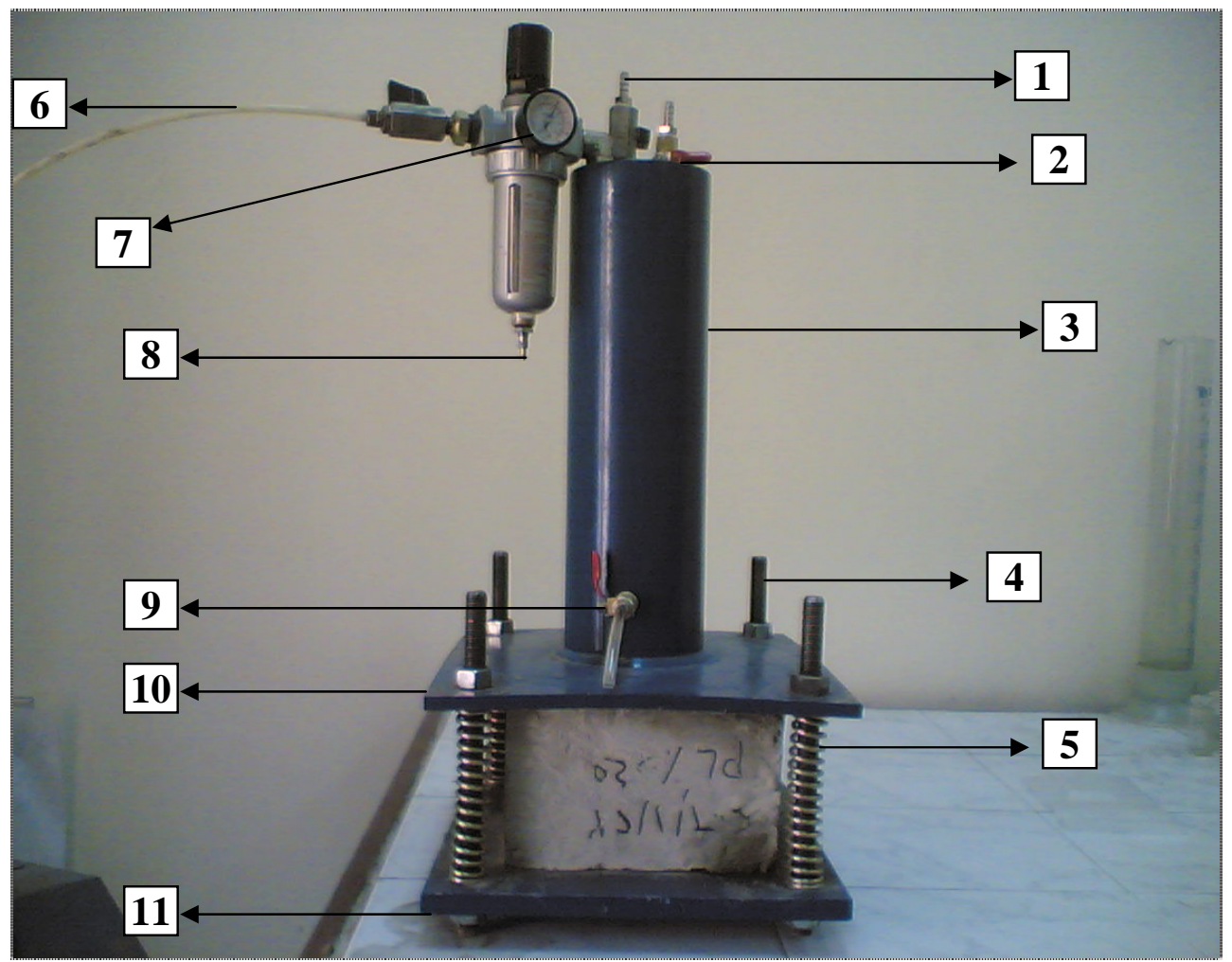

Photo (2) apparatus permeability test
1. Water inter $1 / 4$ in
2. Ventilation (air out)
3. Water tank $\phi 100 \mathrm{~mm}$
4. Screw bolt $\phi 16 \mathrm{~mm}$
5.Spring
6.Air pressure
7.Pressure gauge
8. Water separator
9. Darning

10. Upper plate 30x30x1cm 11.lower plate 30x30x1cm

\section{Experimental tests results}

\subsection{Effect of additions on permeability}

\subsubsection{First case:}

It has been added ADDICRETE DM2 ${ }^{(4)}$ to the mixture by difference ratio. $1 \%, 0.5 \%, 0.45 \%$ , $0.35 \%$ of cement weight, constant ratio from , sand, gravel, cement and water in all tests that will used in research for reaching a suitable ratio from ADDICRETE DM2 and give us a good result to prevent penetration of water to concrete, we can using it as isolation material in underground structure and tunnel. And give us less cost.

Table (1) includes the results of testing three samples, where penetration of water was measured inside the sample after it was broken from the middle of span. The sample without any addition and was divided to (cm). 
The average of the three samples was drowned showing the average line of penetration of water as show in Figure (2)

Table (2) includes the results of testing three samples to all ratios that used from ADDICRETE DM2 material, where penetration of water was measured inside the sample after it was broken from the middle of span. The sample divided to $(\mathrm{cm} \mathrm{s})$.an additive named (ADDICRETE DM2). was added to the sample with a ratio of $1 \%, 0.5 \%, 0.45 \%$, and $0.35 \%$ of cement weight.

The average of the three samples was drowned showing the average line of penetration of water as show in Figure (3)

\subsubsection{Comparing the results of the first case}

Of testing with respect to the ratios of the additives ADDICRETE DM2 0.0\%, 0.35\%, 0.45\%, $0.5 \%, 1 \%$ of cement weight the figure (3) shows the difference and pointing to the ratio of $0.45 \%$ that the best result as it was the smallest value of penetration in concrete with respect to the others.

\section{1.3. Second case:}

It has been addition PLASTOCRETE- $\mathrm{N}$ to the mixture by difference ratio. $1 \%, 0.5 \%, 0.45 \%$ , $0.35 \%$ of cement weight, constant ratio from , sand, gravel, cement and water in all tests that will used in research for reaching a suitable ratio from PLASTOCRETE $-\mathrm{N}^{5}$ and give us a good result in prevent penetration of water to concrete we can using it as isolation material in underground structure and tunnel. And give us less cost.

Table (3) includes the results of testing three samples to all ratios that used from plastocrete $\mathrm{N}$ material,where penetration of water was measured inside the sample after it was broken from the middle of span. The sample divided to ( $\mathrm{cm} \mathrm{s}$ ).an additive named (PLASTOCRETE- N), was added to the sample with a ratio of $1 \%, 0.5 \%, 0.45 \%$, and $0.35 \%$ of cement weight.

The average of the three samples was drowned showing the average line of penetration of water as show in Figure (4)

\subsubsection{Comparing the results the second case}

Of testing with respect to the ratios of the additives PLASTOCRETE- N $0.0 \%, 0.35 \%, 0.45 \%$, $0.5 \%, 1 \%$ of cement weight . Figure (4) shows the difference and pointing to the ratio of $0.5 \%$ that the best result as it was the smallest value of penetration in concrete with respect to the others. 
Proceedings of the 6th ICCAE Conf. 16-18 May, 2006

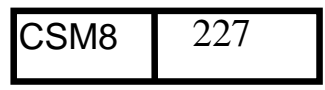

Table (1) Results of testing three samples without using Admixture

\begin{tabular}{|c|c|c|c|c|c|c|}
\hline \multirow{2}{*}{ 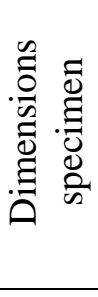 } & \multirow{2}{*}{ 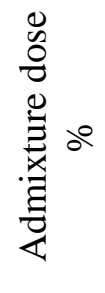 } & \multirow{2}{*}{ 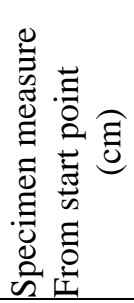 } & \multicolumn{3}{|c|}{ Penetration distance (mm) } & \multirow{2}{*}{ 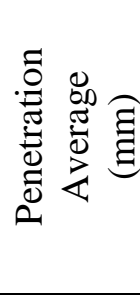 } \\
\hline & & & $\begin{array}{c}\text { Specimen } \\
\text { (1) }\end{array}$ & $\begin{array}{l}\text { Specimen } \\
\text { (2) }\end{array}$ & $\begin{array}{c}\text { Specimen } \\
\text { (3) }\end{array}$ & \\
\hline 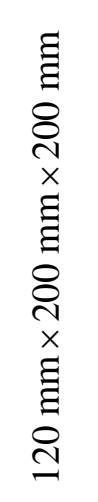 & 0 & $\begin{array}{c}0 \\
2 \\
4 \\
6 \\
8 \\
10 \\
12 \\
14 \\
16 \\
18 \\
20\end{array}$ & $\begin{array}{c}0 \\
18 \\
27 \\
27 \\
29 \\
24 \\
22 \\
27 \\
31 \\
26 \\
0\end{array}$ & $\begin{array}{c}0 \\
0 \\
8 \\
16 \\
19 \\
22 \\
26 \\
21 \\
15 \\
10 \\
0\end{array}$ & $\begin{array}{c}0 \\
0 \\
10 \\
22 \\
25 \\
24 \\
30 \\
36 \\
33 \\
28 \\
0\end{array}$ & $\begin{array}{c}0 \\
6 \\
15 \\
21.6 \\
24.3 \\
23.3 \\
26 \\
28 \\
26.3 \\
21.3 \\
0\end{array}$ \\
\hline
\end{tabular}

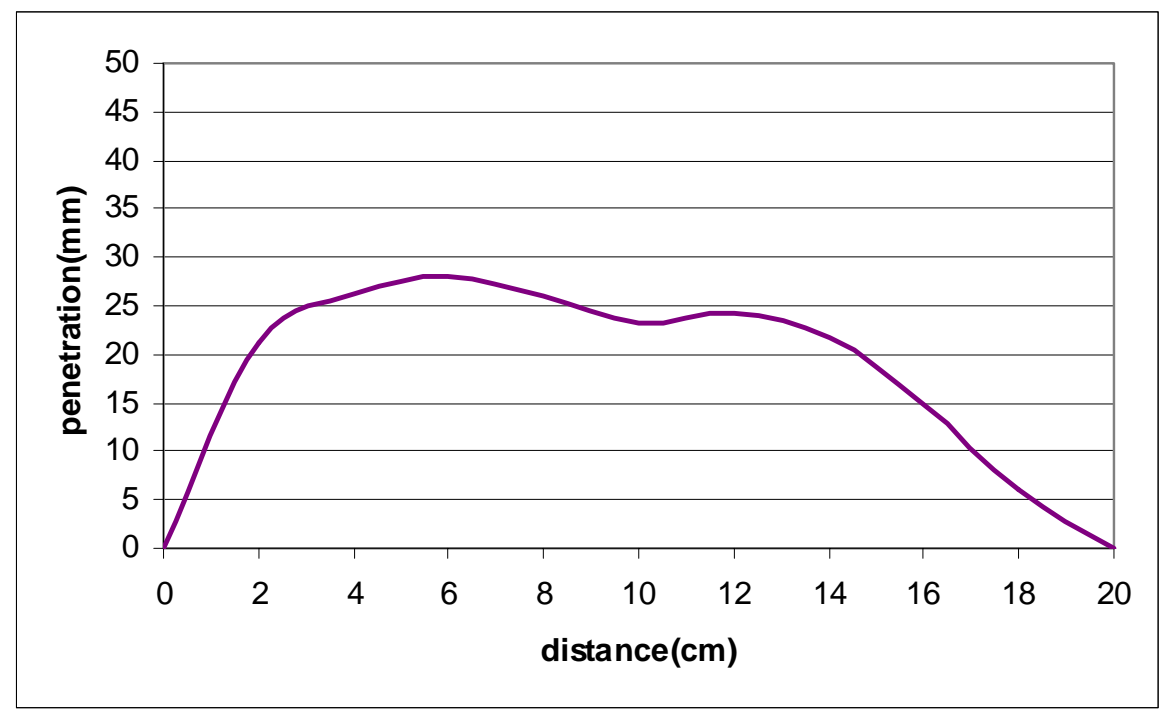

Figure (2) Water penetration average curve in specimen without any admixture 
Table (2) Summary of the different ratios with the average water penetration depths by using ADDICRETE DM2

\begin{tabular}{|l|c|c|c|c|c|}
\hline $\begin{array}{l}\text { Specimen } \\
\text { Measure } \\
\text { From start } \\
\text { Point (cm) }\end{array}$ & $\begin{array}{c}\text { Penetration } \\
\text { Average } \\
\text { ADDICRETE } \\
\text { DM2 }\end{array}$ & $\begin{array}{c}\text { Penetration } \\
\text { Average } \\
\text { ADDICRETE } \\
\text { DM2 }\end{array}$ & $\begin{array}{c}\text { Penetration } \\
\text { Average } \\
\text { ADDICRETE } \\
\text { DM2 }\end{array}$ & $\begin{array}{c}\text { Penetration } \\
\text { Average } \\
\text { ADDICRETE } \\
\text { DM2 }\end{array}$ & $\begin{array}{c}\text { Penetration } \\
\text { Average } \\
\text { ADDICRETE } \\
\text { DM2 }\end{array}$ \\
\hline 0 & 0 & $1 \%$ & $0.5 \%$ & $0.45 \%$ & $0.35 \%$ \\
2 & 6 & 10 & 0 & 0 & 0 \\
4 & 15 & 11.3 & 14.6 & 0 & 2 \\
6 & 21.6 & 21.3 & 11.3 & 0 & 10 \\
8 & 24.3 & 27.3 & 11 & 14.3 & 16.6 \\
10 & 23.3 & 21.6 & 15.6 & 4.3 & 14 \\
12 & 26 & 19 & 7 & 1 & 23.3 \\
14 & 28 & 14 & 6 & 0 & 19.3 \\
16 & 26.3 & 7.6 & 5.6 & 0 & 9.6 \\
18 & 21.3 & 7.6 & 3.3 & 0 & 5 \\
20 & 0 & 2.3 & 0 & 0 & 2.3 \\
& & & & & 0 \\
\hline
\end{tabular}

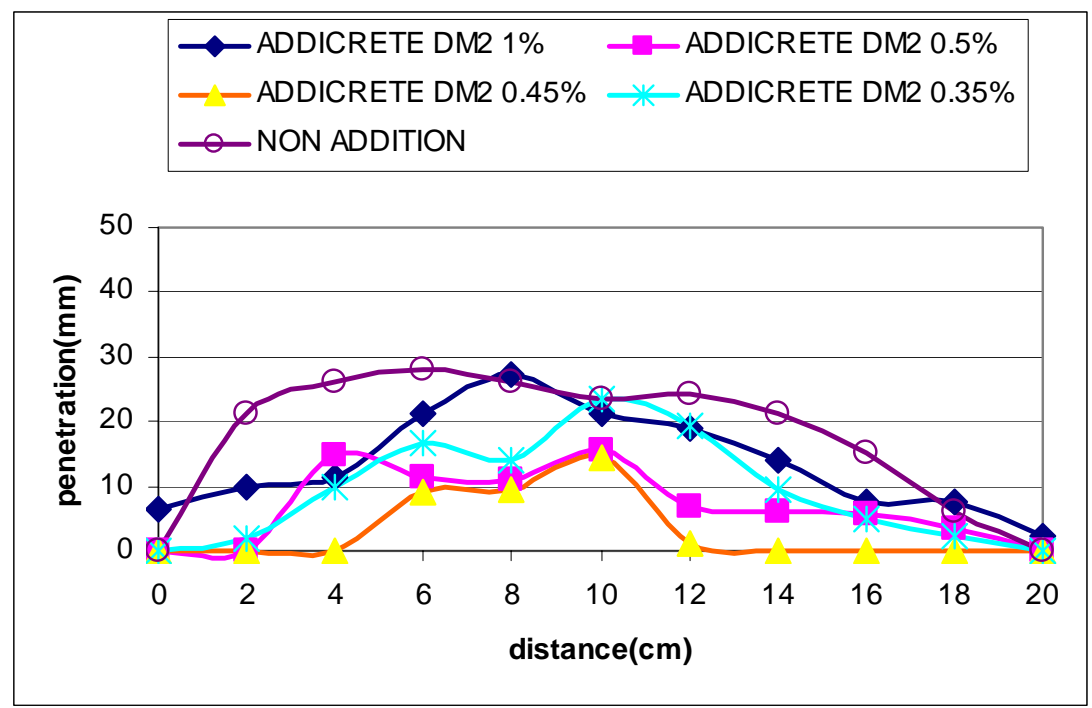

Figure (3) Average water Penetration curves with different ADDICRETE DM2 ratios. Table (3) Summary of the different ratios with the average water penetration depths PLASTOCRETE -N. 
Proceedings of the 6th ICCAE Conf. 16-18 May, 2006

\begin{tabular}{|c|c|c|c|c|c|}
\hline $\begin{array}{l}\text { Specimen } \\
\text { Measure } \\
\text { From start } \\
\text { Point } \\
(\mathrm{cm}) \\
\end{array}$ & $\begin{array}{c}\text { Penetration } \\
\text { Average } \\
\text { PLASTOCRETE } \\
\mathrm{N} \\
0 \% \\
\end{array}$ & $\begin{array}{c}\text { Penetration } \\
\text { Average } \\
\text { PLASTOCRETE } \\
\mathrm{N} \\
1 \% \\
\end{array}$ & $\begin{array}{c}\text { Penetration } \\
\text { Average } \\
\text { PLASTOCRETE } \\
\mathrm{N} \\
0.5 \% \\
\end{array}$ & $\begin{array}{c}\text { Penetration } \\
\text { Average } \\
\text { PLASTOCRETE } \\
\mathrm{N} \\
0.45 \% \\
\end{array}$ & $\begin{array}{c}\text { Penetration } \\
\text { Average } \\
\text { PLASTOCRETE } \\
\mathrm{N} \\
0.35 \% \\
\end{array}$ \\
\hline 0 & 0 & 0 & 2.3 & 11 & 0 \\
\hline 2 & 6 & 15.6 & 5.6 & 15.6 & 13.3 \\
\hline 4 & 15 & 23 & 17 & 20.6 & 21.3 \\
\hline 6 & 21.6 & 19.3 & 9.3 & 16.3 & 26.6 \\
\hline 8 & 24.3 & 18.6 & 13.6 & 17.3 & 26 \\
\hline 10 & 23.3 & 23 & 11 & 22 & 21 \\
\hline 12 & 26 & 22.3 & 15.6 & 23.6 & 21.3 \\
\hline 14 & 28 & 21.3 & 17.6 & 22 & 15.6 \\
\hline 16 & 26.3 & 18.3 & 7.3 & 20 & 21.6 \\
\hline 18 & 21.3 & 9 & 5 & 17.3 & 17 \\
\hline 20 & 0 & 0 & 1.3 & 9.6 & 3 \\
\hline
\end{tabular}

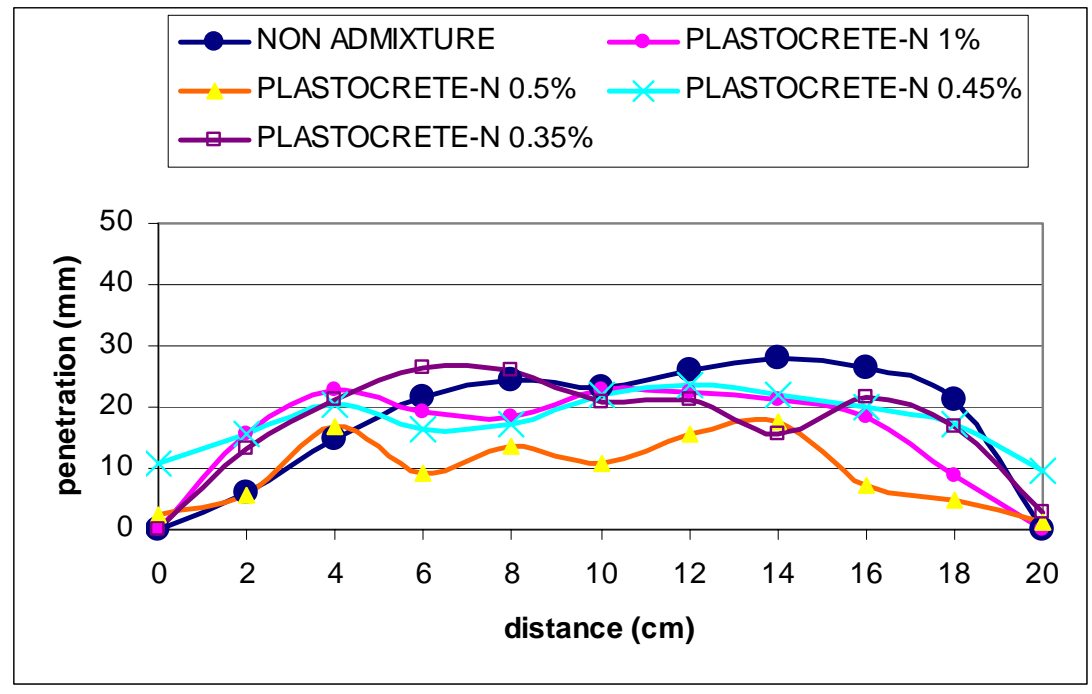

Figure (4) Average water penetration curves with different PLASTOCRETE -N ratios

\subsection{Effect the Admixture on Compressive strength}

The specimen was tested at 28 day

5.2.1. First case: Admixture of ADDICRETE DM2 by ratio $0.35 \%, 0.45 \%, 0.5 \%, 1 \%$ of cement weight on concrete and we have good results, the best ratio was $0.45 \%$, we have good stress at ratio $(0.45 \%)$ compared with respected to the others and without any admixture on concrete it shows the flowing Table (4) and Figure (5)

These results insure the effectiveness of the ADDICRETE DM2 to improve properties of concrete from against reducing permeability and increase the resistance 


\subsubsection{Second case:}

Admixture of PLASTOCRETE- $\mathrm{N}$ by ratio $0.35 \%, 0.45 \%, 0.5 \%, 1 \%$ of cement weight on concrete and we have good results, the best ratio $0.5 \%$, we have good stress at ratio $(0.5 \%)$ compared with respected to the others and without any admixture on concrete it shows the flowing Table (5) and Figure (6) These results insure effectiveness the PLASTOCRETE $N$ to improve properties of concrete from against reducing permeability and increase the resistance Figures (7)and (8)by comparing between addicrete DM2 and plastocrete- $\mathrm{N}$ of so that (permeability, compressive strength), the ratio $0.45 \%$ of addicrete is the best ratio for reducing permeability of concrete

Table (4) Compressive strength by using different ADDICRETE DM2 ratios.

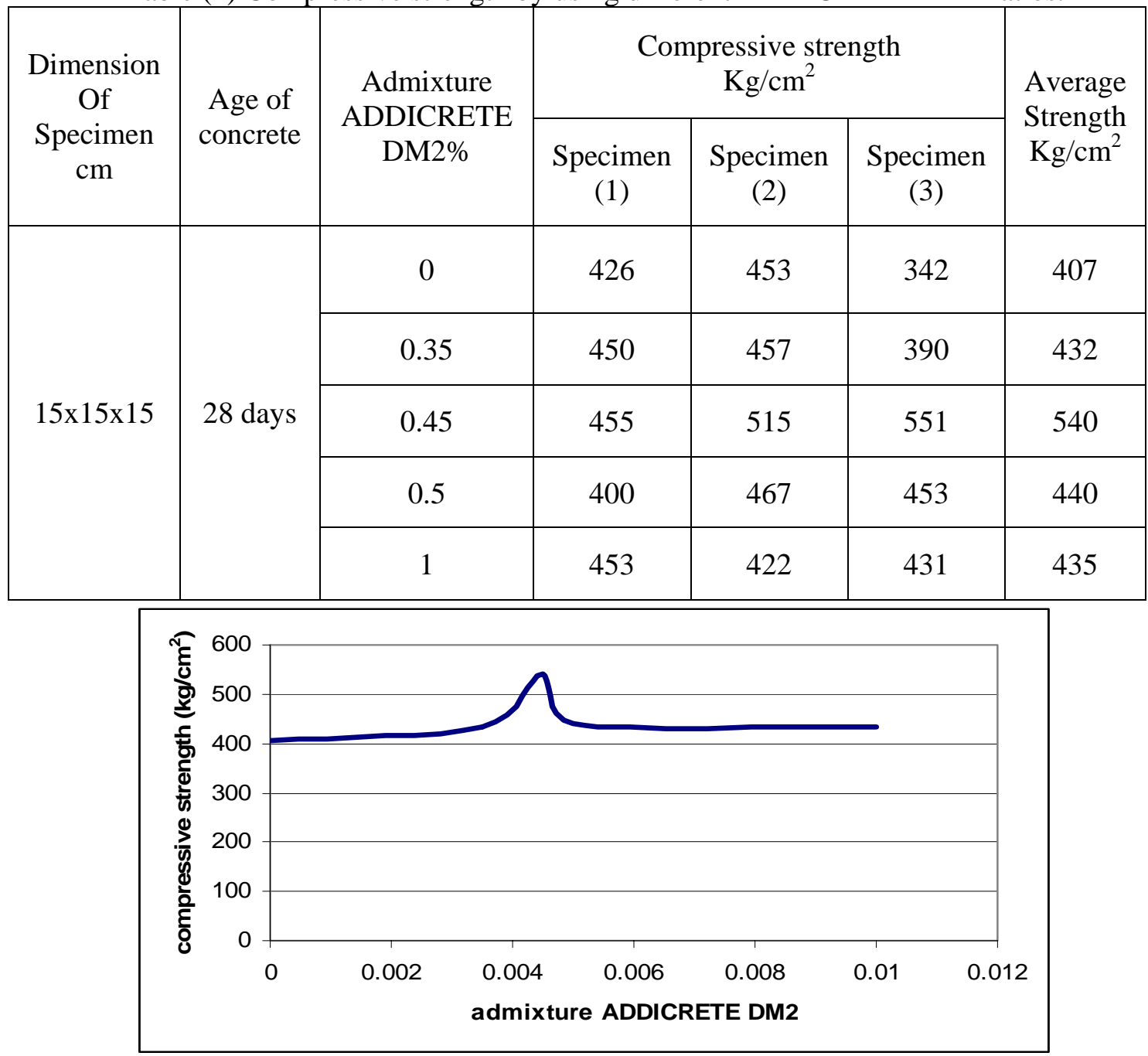

Figure (5) Average compressive strength curves with different ADDICRETE DM2 ratios

Table (5) Compressive strength by using different PLASTOCRETE N ratios. 
Proceedings of the 6th ICCAE Conf. 16-18 May, 2006

\begin{tabular}{|l|l|}
\hline CSM8 & 231 \\
\hline
\end{tabular}

\begin{tabular}{|c|c|c|c|c|c|c|}
\hline \multirow{2}{*}{$\begin{array}{l}\text { Dimension } \\
\text { Of } \\
\text { Specimen } \\
\text { cm }\end{array}$} & \multirow{2}{*}{$\begin{array}{c}\text { Age of } \\
\text { concrete }\end{array}$} & \multirow{2}{*}{$\begin{array}{c}\text { Admixture } \\
\text { Plastocrete N } \\
\%\end{array}$} & \multicolumn{3}{|c|}{$\begin{array}{c}\text { Compressive strength } \\
\mathrm{Kg} / \mathrm{cm}^{2}\end{array}$} & \multirow{2}{*}{$\begin{array}{c}\text { Average } \\
\text { Strength } \\
\mathrm{Kg} / \mathrm{cm}^{2}\end{array}$} \\
\hline & & & $\begin{array}{c}\text { Specimen } \\
\text { (1) }\end{array}$ & $\begin{array}{c}\text { Specimen } \\
\text { (2) }\end{array}$ & $\begin{array}{c}\text { Specimen } \\
\text { (3) }\end{array}$ & \\
\hline \multirow{5}{*}{ 15X15X15 } & \multirow{5}{*}{28 days } & 0 & 426 & 453 & 342 & 407 \\
\hline & & 0.35 & 422 & 400 & 414 & 412 \\
\hline & & 0.45 & 441 & 442 & 390 & 424 \\
\hline & & 0.5 & 453 & 444 & 398 & 432 \\
\hline & & 1 & 401 & 444 & 401 & 415 \\
\hline
\end{tabular}

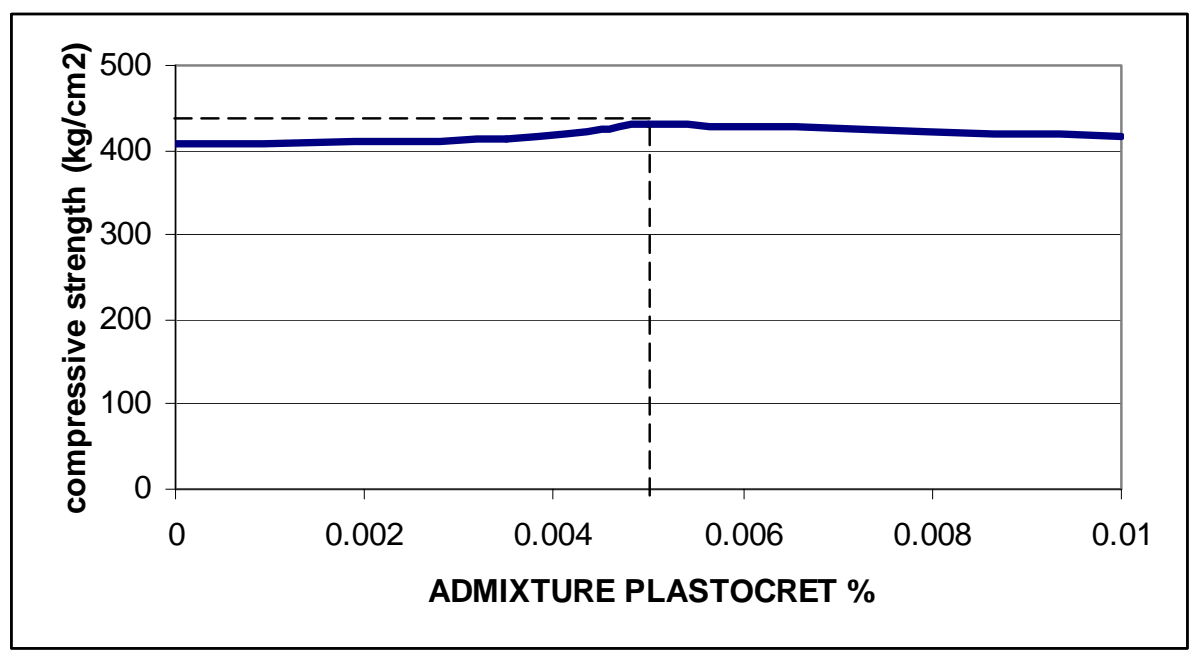

Figure (6) Average compressive strength curves with different PLASTOCRETE N ratios 


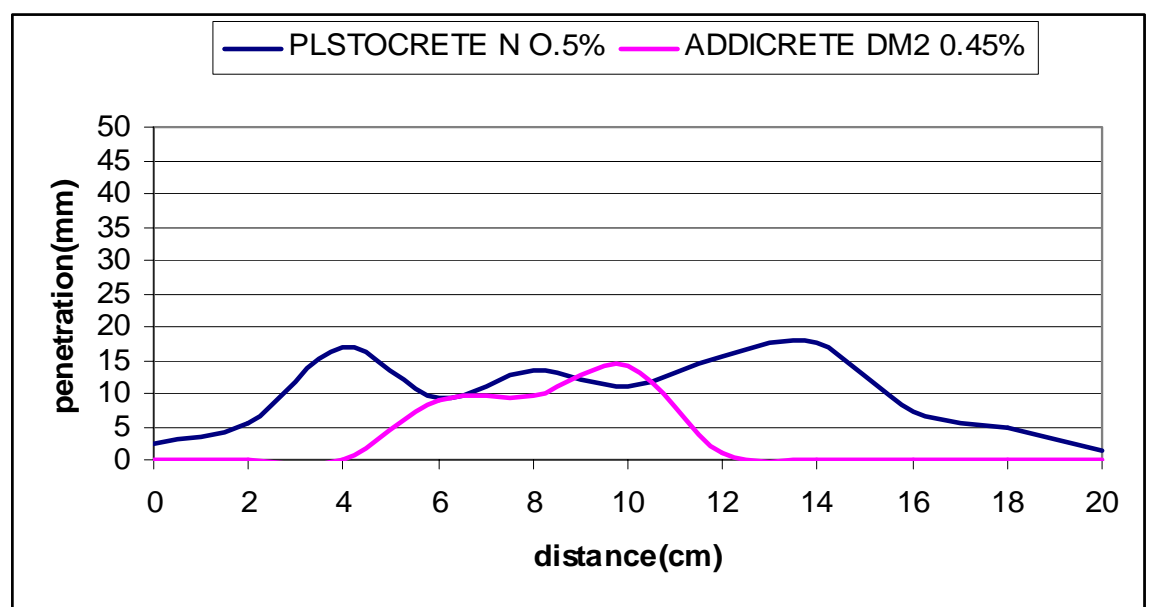

Figure (7) Comparison of the 0.45\% ADDICRETE DM2 and 0.50\% PLASTOCRETE-N permeability test results

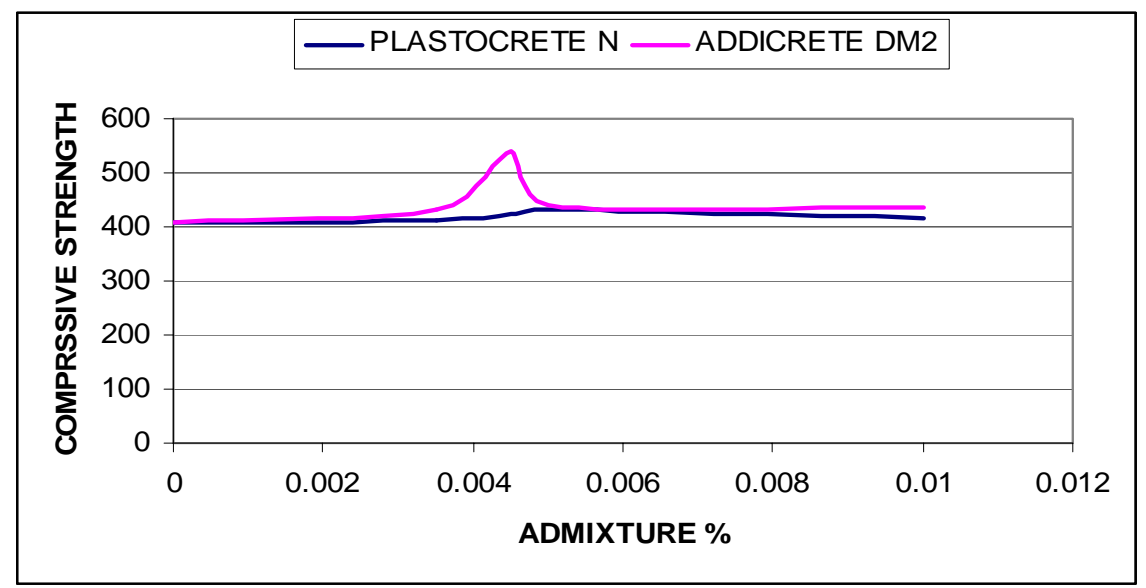

Figure (8) Comparison of the 0.45\% ADDICRETE DM2 and 0.50\% PLASTOCRETE-N compressive strength test results

\section{Conclusions}

1) The research quantify effectiveness the addition materials in reducing permeability and using in concrete isolation operation of underground structures

2) the results insure the effectiveness of ADDICRETE DM2 and PLASTOCRETE-N to improve properties of concrete to reduce permeability and to increase the resistance.

3) The ratio of $0.45 \%$ of cement weight of ADDICRETE DM2 gives the smallest value of $14.3 \mathrm{~mm}$ water penetration.

4) The ratio of $0.50 \%$ of cement weight of PLASTOCRETE-N gives the smallest value of $17.6 \mathrm{~mm}$ water penetration. 
5) The ratio $0.45 \%$ of cement weight of ADDICRETE DM2 is the best ratio from ADDICRETE DM2 and PLASTOCRETE-N .It gives a good results in reducing permeability about $50 \%$ and increasing the compressive strength of concrete

\section{References}

1. By Darmawan ludirdja , Richard 1 . berger, and $\mathrm{j}$. francis young "simple method for measuring water permeability of concrete " ACI Materials journal , V. 86, N0 .1989

2.Figg , j w., method of measuring the air and water permeability of concrete, magazine of concrete research , (London) ,V. 25, no.85, Dec.1983 , pp. 213-219

3. By r.p.khatri and V.sirivivatnanon."methods for the determination of water permeability of concrete"ACI Materials journal, V.94,no.3,1997

4. Sika Egypt for construction chemicals s.a.e "plastocrete $\mathrm{N}$ waterproofing concrete Admixture, Edition 10.2003

5. K.Mostsfa, B.Nassif\& partners "ADDICRETE DM2 waterproofing and anti-chemical agent for concrete and mortar", chemicals for modern building. 